\title{
STUDI KOMPARASI FAKTOR-FAKTOR YANG MEMPENGARUHI KINERJA BANK UMUM SYARIAH (BUS) DAN BANK PEMBIAYAAN RAKYAT SYARIAH (BPRS)
}

\author{
Yeni Fitriani Somantri \\ Fakultas Ekonomi Universitas Perjuangan Tasikmalaya \\ yenifitriani13@yahoo.com
}

\begin{abstract}
Abstrak
Penelitian ini merupakan studi komparasi dengan menguji faktor-faktor yang mempengaruhi kinerja Bank Umum Syariah (BUS) dan Bank Pembiayaan Rakyat Syariah (BPRS) di Indonesia. Faktor-faktor yang di uji meliputi variabel risiko pembiayaan (NPF), kualitas aktiva produktif (KAP), tingkat perputaran piutang (ART), dana pihak ketiga (DPK), volume pembiayaan (FDR) sebagai variabel independen dan rentabilitas (NOM) sebagai variabel dependen, serta total aset sebagai variabel kontrol. Data yang digunakan dalam penelitian ini diperoleh dari Laporan Keuangan Triwulanan Bank Umum Syariah dan BPR Syariah periode 2011-2013. Teknik sampling yang digunakan adalah purposive sampling. Sampel dalam penelitian ini terdiri dari 5 (lima) Bank Umum Syariah dan 25 (dua puluh lima) BPR Syariah. Teknik analisis data yang digunakan dalam penelitian ini adalah analisis regresi linier berganda dan uji chow dimana sebelumnya data telah diuji dengan pengujian asumsi klasik meliputi uji normalitas, heteroskedastisitas, multikolinieritas dan autokorelasi. Hasil penelitian ini menunjukkan bahwa NPF dan DPK tidak berpengaruh terhadap tingkat rentabilitas (NOM), sedangkan KAP, perputaran piutang (ART), dan volume pembiayaan (FDR) berpengaruh terhadap tingkat rentabilitas (NOM) pada bank umum syariah. Sedangkan hasil analisis data yang telah dilakukan pada BPR Syariah menunjukkan bahwa risiko pembiayaan (NPF), kualitas aktiva produktif (KAP), perputaran piutang (ART), dana pihak ketiga (DPK), dan volume pembiayaan (FDR) tidak berpengaruh terhadap tingkat rentabilitas (NOM) pada BPRS. Berdasarkan hasil uji chow bahwa model regresi pada bank umum syraiah dan BPRS adalah sama, dengan demikian hubungan antara setiap variabel untuk masing-masing model regresi mempunyai pengaruh yang sama dan dalam katageri sejenis yaitu syariah.

Kata kunci : risiko pembiayaan (NPF), kualitas aktiva produktif (KAP), tingkat perputaran piutang (ART), dana pihak ketiga (DPK), volume pembiayaan (FDR), rentabilitas (NOM), total aset, Bank Umum Syariah, BPR Syariah.

\section{PENDAHULUAN}

Perkembangan perbankan syariah di Indonesia telah menjadi tolak ukur keberhasilan eksistensi ekonomi syariah. Krisis moneter yang terjadi pada tahun 1998 telah menenggelamkan bank-bank konvensional dan banyak yang dilikuidasi karena kegagalan sistem bunga. Sementara perbankan yang menerapkan prinsip syariah dalam

bertahan. Dilihat dari segi kegiatan operasionalnya, bank syariah sudah jelas memiliki perbedaan yang khas dengan bank konvensional. Perbedaan tersebut begitu mendasar, yaitu tidak diterapkannya sistem bunga pada bank syariah dan sebagai gantinya dengan menggunakan konsep profit and loss sharing (PLS), baik pada sisi liabilities maupun asset.
\end{abstract} kegiatan operasionalnya dapat mampu 
Rentabilitas merupakan indikator yang paling penting untuk mengukur kinerja suatu bank. Muljono (1996) menyatakan bahwa rentabilitas atau profitabilitas adalah rasio untuk mengetahui kemampuan bank menghasilkan keuntungan baik dari kegiatan operasional bank yang bersangkutan maupun dari hasil-hasil non operasionalnya. Penilaian rentabilitas dimaksudkan untuk menilai kemampuan bank syariah dalam menghasilkan laba. Adapun menurut Brigham dan Houston (2010), untuk mengukur profitabilitas bank, biasanya menggunakan rasio profitabilitas.

$\begin{array}{cr}\text { Faktor-faktor } & \text { yang } \\ \text { mempengaruhi rentabilitas }\end{array}$
profitabilitas bank dapat bersumber dari berbagai kinerja operasi yang ditunjukkan oleh beberapa indikator. Sebagaimana yang telah dijelaskan diawal bahwa rentabilitas merupakan kemampuan perusahaan dalam menghasilkan keuntungan dengan semua modal yang bekerja di dalamnya. Menurut Harahap (2007) rasio rentabilitas atau disebut juga profitabilitas menggambarkan kemampuan perusahaan mendapatkan laba melalui semua kemampuan, dan sumber yang ada seperti kegiatan penjualan, kas, modal, jumlah karyawan, jumlah cabang, dan sebagainya.

Dalam penelitian ini, penulis menggunakan net operating margin (NOM). Adapun net operating margin (NOM) merupakan variabel pengukur tingkat rentabilitas selain ROA (Setiawan, 2009). Nilai NOM tersebut dihasilkan dari membagi laba operasional dengan aktiva produktif. Alasan dipilihnya NOM sebagai variabel dependen merujuk pada penelitian Setiawan (2009). Pada penelitian tersebut, NOM digunakan untuk menghitung rentabilitas bagi bank syariah dan NOM (Net Operating Margin) merupakan rasio utama (Surat Edaran Bank Indonesia (SEBI) No. 9 Tahun 2007 mengenai Sistem Penilaian Tingkat Kesehatan Bank Umum Berdasarkan Prinsip Syariah. Melalui hasil penghitungan rasio ini diharapkan dapat diketahui kemampuan aktiva produktif bank syariah dalam menghasilkan laba.

Melalui penelitian ini, penulis ingin mencoba untuk menganalisis faktor-faktor apa yang paling dominan mempengaruhi tingkat profitabilitas dari keduanya, kemudian adanya indikator size perusahaan sebagai variabel kontrol, juga terkait dengan perkembangan yang ada dan hubungannya dengan sasaran penyaluran pembiyaan yang dilakukan oleh bank umum syariah (BUS) dan bank pembiayaan rakyat syariah (BPRS). Sehingga, dapat diperoleh perbedaannya. Hasil penelitian yang dilakukan oleh Islam (2012) yang dilakukan di Malaysia menunjukkan bahwa kesehatan keuangan Bank Rakyat (BR) berada dalam posisi yang lebih baik dibandingkan dengan Bank Simpanan Nasional (BSN).

Berdasarkan paparan di atas, penulis tertarik untuk melakukan penelitian mengenai "Studi Komparasi Faktor-faktor yang Mempengaruhi Kinerja Bank Umum Syariah (BUS) dan Bank Pembiayaan Rakyat Syariah (BPRS)". Adapun yang membedakan penelitian ini dengan penelitian sebelumnya adalah tingkat kinerja yang dikukur dengan tingkat rentabilitas, jumlah sampel, dan rentang waktu periode penelitian. Dalam penelitian ini tingkat rentabilitas menggunakan Net Operating Margin (NOM), yang menjadi sampel penelitian adalah bank umum syariah dan BPRS yang ada di Indonesia, serta rentang waktu periode penelitian dari tahun 2011-2013. Sedangkan pada penelitian 
sebelumnya tingkat rentabilitas menggunakan ROA, rentang waktu penelitian dari tahun 2003-2007 dan tidak adanya perbandingan antar kategori jenis bank.

\section{KERANGKA TEORITIS}

\section{Syariah Enterprise Theory dan Stakeholders Theory}

Meutia (2010) berpendapat bahwa dalam shariah enterprise theory, Allah adalah sumber amanah utama. Sedangkan sumber daya yang dimiliki para stakeholders adalah amanah dari Allah yang di dalamnya melekat sebuah tanggung jawab untuk menggunakan dengan cara dan tujuan yang ditetapkan oleh Sang Maha Pemberi Amanah. Shariah Enterprise Theory merupakan enterprise theory yang telah diinternalisasi dengan nilai-nilai Islam guna menghasilkan teori yang transendental dan lebih humanis (Purwitasari dan Chariri, 2010).

$$
\text { Menurut Triyuwono dalam }
$$

Purwitasari dan Chariri (2010), enterprise theory mampu mewadahi kemajemukan masyarakat (stakeholders). Hal ini karena konsep enterprise theory menunjukkan bahwa kekuasaan ekonomi tidak lagi berada di satu tangan (shareholders), melainkan berada pada banyak tangan, yaitu stakeholders (Triyuwono, 2003). Oleh karena itu, enterprise theory ini lebih tepat untuk bagi suatu sistem ekonomi yang mendasarkan diri pada nilai-nilai syariah. Namun demikian, menurut Slamet (2001) dalam Purwitasari dan Chariri (2010), enterprise theory masih perlu diinternalisasi dengan nilai-nilai Islam agar dapat digunakan sebagai teori dasar bagi suatu ekonomi dan akuntansi Islam.

$$
\text { Selain Syariah Enterprise }
$$

Theory, pada penelitian ini juga digunakan Stakeholders Theory. Gray, dkk dalam Purwitasari dan Chariri
(2010) berargumen bahwa stakeholder theory adalah (biasanya) pandangan borjuis secara eksplisit di dunia dilihat dari perspektif manajemen organisasi yang peduli strategis dengan kesuksesan perusahaan. Menurut Iqbal, dkk dalam Arsyianti (2012), dalam Islam, stakeholder merupakan berbagai pihak yang memiliki hak dengan risiko akibat dari tindakan perusahaan baik secara sukarela maupun tidak. Sehingga stakeholder bukan hanya mereka yang hubungannya terkait secara eksplisit tertera dalam kontrak ataupun transaksi, tetapi juga mereka yang secara implisit sebenarnya memiliki keterkaitan dengan aktifitas perusahaan. Kemudian, Islam mewajibkan setiap perusahaan untuk menghormati unwritten codes of conduct bagi siapa saja stakeholder yang mungkin memiliki keterkaitan dengan aktifitas perusahaan.

\section{Bank Umum Syariah dan Bank Pembiayaan Rakyat Syariah}

Bank Islam atau selanjutnya disebut dengan Bank Syariah, adalah bank yang beroperasi dengan tidak mengandalkan pada bunga. Bank syariah juga dapat diartikan sebagai lembaga keuangan/perbankan yang operasional dan produknya dikembangkan berlandaskan Al-Qur'an dan Hadits Nabi SAW.

Jika dilihat dari pengertiannya, perbedaannya terletak pada kegiatannya, yaitu bank umum memberikan jasa dalam lalu lintas pembayaran sedangkan pada BPR tidak. Jasa lalu lintas pembayaran itu adalah jasa yang diberikan perbankan untuk nasabah misalnya kliring, dan jual beli valuta asing. Maka dari itu BPR tidak terlibat dalam kliring dan kegiatan usaha valuta asing. Selanjutnya ditinjau dari kegiatan usaha bank umum dan BPR, perbedaannya terletak pada bentuk simpanan dana yang dihimpun 
dari masyarakat. BPR tidak menghimpun dana dalam bentuk giro dan sertifikat deposito, hanya menerima dalam bentuk tabungan dan deposito. Maka dari itu, BPR tidak dapat melakukan transaksi giral. Sedangkan bank umum dapat melakukan transaksi giral.

\section{Kinerja Keuangan Perbankan}

Pendapat Jumingan dalam Lestari dan Sugiharto (2007) kinerja keuangan bank merupakan gambaran kondisi keuangan bank pada periode tertentu baik menyangkut aspek penghimpunan dana maupun penyaluran dana yang biasanya diukur dengan indikator kecukupan modal, likuiditas dan profitabilitas bank.

Muljono (1996) menyatakan bahwa rentabilitas atau profitabilitas adalah rasio untuk mengetahui kemampuan bank menghasilkan keuntungan baik dari kegiatan operasional bank yang bersangkutan maupun dari hasil-hasil non operasionalnya. Bagi bank syariah dalam menghitung rentabilitas, net operating margin (NOM) merupakan rasio utama (Surat Edaran Bank Indonesia (SEBI) No. 9 Tahun 2007 mengenai Sistem Penilaian Tingkat Kesehatan Bank Umum Berdasarkan Prinsip Syariah, dalam penelitian Setiawan (2009).

\section{Risiko Pembiayaan, Kualitas Aktiva Produktif, Tingkat Perputaran Piutang, Dana Pihak Ketiga, Volume Pembiayaan, dan Size Perusahaan}

Salah satu risiko yang muncul akibat semakin kompleknya kegiatan perbankan adalah munculnya non performing loan (NPL) yang semakin besar. Atau dengan kata lain semakin besar skala operasi suatu bank maka aspek pengawasan semakin menurun, sehingga NPL semakin besar atau resiko kredit semakin besar (Mawardi, 2005). Pada bank syariah, non performing loan (NPL) disebut dengan non performing financing (NPF).

Kualitas Aktiva Produktif merupakan earnings asset quality, yaitu tolok ukur untuk menilai tingkat kemungkinan diterimanya kembali dana yang ditanamkan dalam aktiva produktif (pokok termasuk bunga) berdasarkan kriteria tertentu. Aktiva produktif merupakan penanaman dana bank syariah baik dalam rupiah maupun valuta asing dalam bentuk pembiayaan, piutang, qardh, surat berharga syariah, penempatan, penyertaan modal, penyertaan modal sementara, komitmen dan kontinjensi pada transaksi rekening administratif serta sertifikat wadiah Bank Indonesia.

Perputaran piutang merupakan total pendapatan (sales atau revenue atau margin) dibagi dengan jumlah piutang perusahaan. Pada perbankan syraiah, total pendapatan dianalogikan dengan total penyaluran pembiayaan dan jumlah piutang dinalogikan dengan jumlah piutang murabahah. Rasio perputaran piutang biasa digunakan untuk menganalisis terhadap modal kerja, karena dapat memberikan penilaian terhadap kinerja mengenai seberapa cepat piutang perusahaan berputar kembali menjadi kas.

Menurut Kasmir (2007), dana pihak ketiga adalah dana yang berasal dari masyarakat luas yang merupakan sumber dana terpenting bagi kegiatan operasional suatu bank dan merupakan ukuran keberhasilan bank jika mampu membiayai operasionalnya dari sumber dana ini. Sumber dana ini merupakan sumber dana terpenting bagi kegiatan operasional bank dan merupakan ukuran keberhasilan bank jika mampu membiayai operasionalnya dari sumber dana ini. 
Volume pembiayaan merupakan jumlah pendanaan yang dikeluarkan oleh bank syariah untuk mendukung investasi yang telah direncanakan selama waktu tertentu dari hasil penghimpunan dana pihak ketiga (Pramuka, 2010). Variabel besarnya pembiayaan ini diukur dengan Financing to Deposit Ratio (FDR). Financing to Deposit Ratio (FDR) adalah perbandingan antara pembiayaan yang diberikan oleh bank dengan dana pihak ketiga yang berhasil dikerahkan oleh bank (Muhammad, 2005).

Ukuran perusahaan adalah suatu skala dimana dapat diklasifikasikan besar kecil perusahaan menurut berbagai cara, antara lain total aktiva, log size, nilai pasar saham, dan lain-lain (Stiawan, 2009). Perusahaan yang memiliki asset yang besar berkesempatan memperoleh profit yang lebih besar.

\section{Kerangka Pemikiran dan Perumusan \\ Model Penelitian}

Penilaian dimaksudkan untuk menilai kemampuan bank syariah dalam menghasilkan laba. Rentabilitas merupakan indikator yang paling penting untuk mengukur kinerja suatu bank. Bank syariah terdiri dari bank umum dan bank pembiayaan rakyat. Adanya perbedaan tersebut (bank umum dan bank pembiayaan rakyat) kemungkinan menimbulkan kinerja yang berbeda. Hal ini berkaitan dengan faktor internal bank, baik dalam menyalurkan maupun memberikan pembiayaan kepada nasabahnya, mengingat ukuran antara bank umum syariah dan BPR syariah berbeda. Ukuran tersebut dapat dilihat dari total aset, sasaran nasabah, dan cakupan wilayah. Berdasarkan uraian pada telaah pustaka dan beberapa penelitian terdahulu, dalam penelitian ini digambarkan suatu model penelitian sebagai berikut:

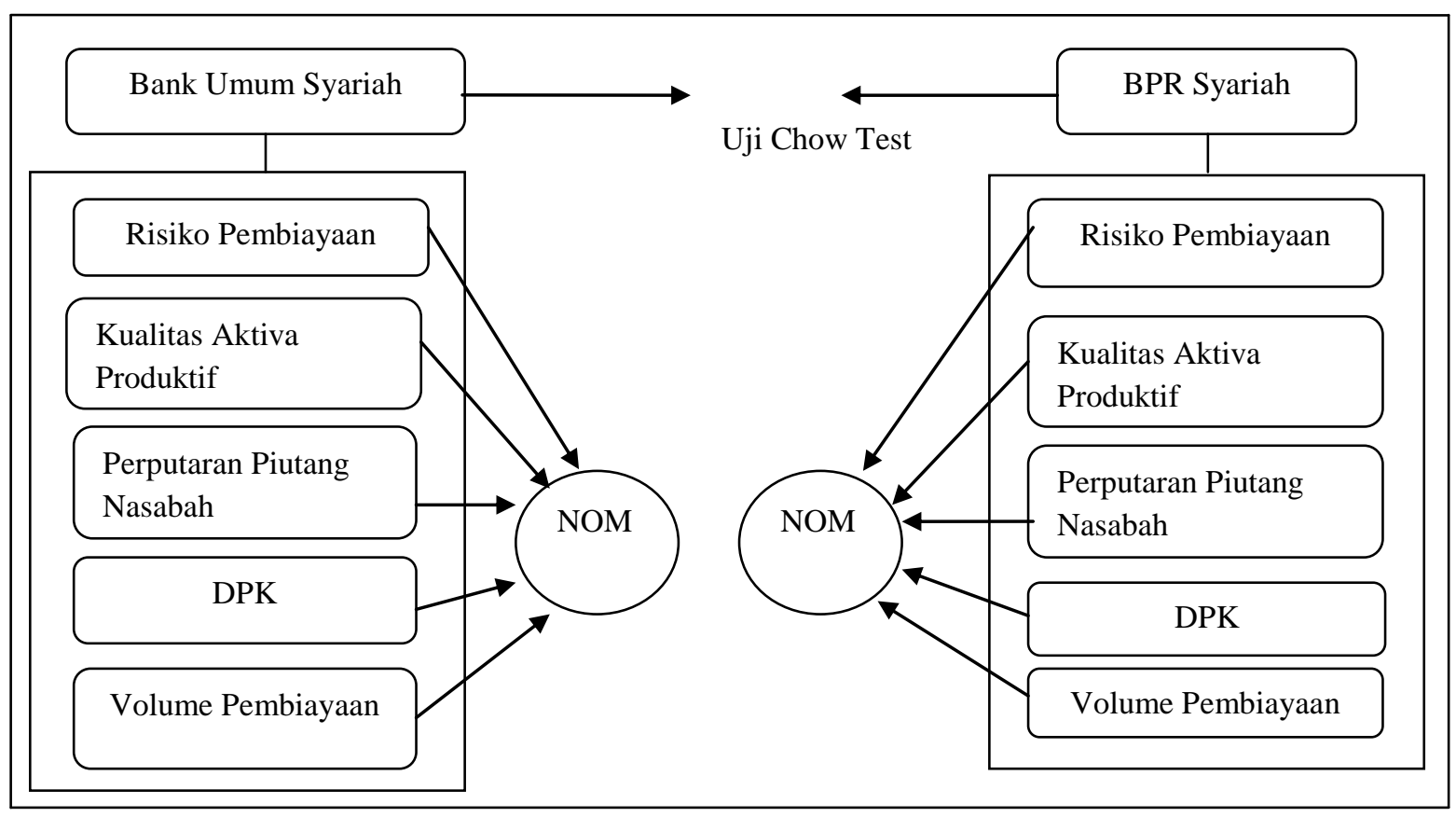

Gambar 1 Model Penelitian 


\section{HIPOTESIS}

\section{Pengaruh Risiko Pembiayaan}

Terhadap Tingkat Rentabilitas Bank Umum Syariah Dengan BPR Syariah

Menurut Zimmerman dalam

Rindhatmono (2005) NPL sangat mempengarunhi kinerja bank terutama kualitas aset dan semakin tinggi NPL maka akan menurunkan pendapatan bank (revenue). Hal tersebut tentu saja berpengaruh pada tingkat rentabilitas bank. Pada bank syariah disebut dengan Non Performing Financing (NPF) yang merupakan suatu rasio yang membandingkan tingkat pembiayaan bermasalah terhadap total pembiayaan yang diberikan. Semakin tinggi rasio ini maka akan semakin buruk kualitas kredit bank yang menyebabkan jumlah kredit bermasalah semakin besar, dan oleh karena itu bank harus menanggung kerugian dalam kegiatan operasionalnya sehingga berpengaruh terhadap penurunan laba dan berpengaruh pada tingkat rentabilitas bank. Hasil penelitian yang dilakukan oleh Stiawan (2009) menunjukkan bahwa NPF berpengaruh terhadap ROA pada bankbank Syariah di Indonesia. Maka, berdasarkan pemaparan diatas, hipotesis 1 yang akan diuji pada penelitian ini adalah:

$\mathrm{H}_{1 \mathrm{a}}$ : Risiko pembiayaan berpengaruh negatif terhadap tingkat rentabilitas pada bank umum syariah

$\mathrm{H}_{1 \mathrm{~b}}$ : Risiko pembiayaan berpengaruh negatif terhadap tingkat rentabilitas pada BPRS

\section{Pengaruh Kualitas Aktiva Produktif terhadap tingkat rentabilitas bank umum syariah dengan BPR syariah}

Aktiva yang produktif sering juga disebut dengan earning assets atau aktiva yang menghasilkan, karena penanaman dana tersebut adalah untuk mencapai tingkat penghasilan (laba) yang diharapkan (Setiawan, 2009). Semakin tinggi rasio ini menunjukkan semakin baik kualitas aktiva produktif bank syariah. Hasil penelitian yang dilakukan oleh Luthfihani (2009) menunjukkan bahwa kualitas aktiva produktif memberikan pengaruh terhadap profitabilitas dan penelitian yang dilakukan oleh Rohimat (2012) menunjukkan bahwa kualitas aktiva produktif berpengaruh terhadap rentabilitas bank. Berdasarkan pemaparan diatas, hipotesis 2 yang akan diuji pada penelitian ini adalah:

$\mathrm{H}_{2 \mathrm{a}}$ : Kualitas aktiva produktif berpengaruh positif terhadap tingkat rentabilitas pada bank umum syariah

$\mathrm{H}_{2 b}$ : Kualitas aktiva produktif berpengaruh positif terhadap tingkat rentabilitas pada BPRS

\section{Pengaruh Perputaran Piutang Terhadap Tingkat Rentabilitas Bank Umum \\ Syariah dengan BPR Syariah}

Pada perbankan syariah, total pendapatan dianalogikan dengan total penyaluran pembiayaan dan jumlah piutang dinalogikan dengan jumlah piutang murabahah. Semakin cepat perputaran piutang maka semakin cepat bagi perusahaan untuk mendapatkan dana dalam bentuk tunai, sehingga posisi keuangan perusahaan tetap terjaga atau dengan kata lain tingkat likuiditas perusahaan semakin baik. Jika demikian, maka kas yang diperoleh dapat dengan segera disalurkan kembali dalam bentuk pembiayaan bagi hasil dan mampu meningkatkan operating margin dengan segera. Theresia (2009) dalam penelitiannya menunjukkan bahwa perputaran piutang usaha berpengaruh signifikan terhadap rentabilitas dan hasil penelitian Rina (2012) menunjukkan bahwa tingkat 
perputaran piutang berpengaruh signifikan terhadap profitabilitas. Berdasarkan pemaparan di atas, maka diajukan hipotesis 3 sebagai berikut:

$\mathrm{H}_{3 \mathrm{a}}$ : Perputaran piutang berpengaruh positif terhadap tingkat rentabilitas pada bank umum syariah

$\mathrm{H}_{3 \mathrm{~b}}$ : Perputaran piutang berpengaruh positif terhadap tingkat rentabilitas pada BPRS

\section{Pengaruh Dana Pihak Ketiga}

Terhadap Tingkat Rentabilitas Bank Umum Syariah dengan BPR Syariah

Dana pihak ketiga diperoleh dengan menjumlahkan giro, tabungan dan deposito. Semakin tinggi rasio ini, maka semakin baik tingkat kepercayaan masyarakat terhadap bank yang bersangkutan, sehingga mampu meningkatkan laba operasional dari hasil menyalurkan DPK dalam bentuk pembiayaan kepada nasabah. Dengan demikian, tingkat rentabilitas pun menjadi meningkat. Hasil penelitian yang dilakukan oleh Sudiyatno dan Suroso (2010) menunjukkan bahwa dana pihak ketiga (DPK) berpengaruh positif dan signifikan terhadap kinerja bank. Hal tersebut juga seiring dengan penelitian yang dilakukan oleh Ayu (2007) menyatakan bahwa tabungan dan deposito mempunyai pengaruh positif dan signifikan terhadap tingkat rentabilitas. Berdasarkan paparan tersebut, maka hipotesis 4 yang diajukan adalah sebagai berikut:

$\mathrm{H}_{4 \mathrm{a}}$ : Dana pihak ketiga berpengaruh positif terhadap tingkat rentabilitas pada bank umum syariah

$\mathrm{H}_{4 b}$ : Dana pihak ketiga berpengaruh positif terhadap tingkat rentabilitas pada BPRS

Pengaruh Volume Pembiayaan
Terhadap Tingkat Rentabilitas Bank
Umum Syariah Dengan BPR Syariah
Financing to deposit ratio (FDR) atau loan to deposit ratio (LDR) merupakan rasio pembiayaan terhadap dana pihak ketiga yang diterima oleh bank. Semakin tinggi FDR mengindikasikan bahwa sebuah bank lebih menekankan keuangannya pada penyaluran hutang/pembiayaan yang lebih banyak. Semakin kecil FDR semakin baik likuiditas bank tersebut. Berdasarkan hasil penelitian Pramuka (2010), menunjukkan bahwa variabel besarnya pembiayaan (FDR) mempunyai pengaruh positif dan signifikan terhadap profitabilitas bank umum syariah. Hasil penelitian Stiawan (2009) juga menunjukkan bahwa FDR berpengaruh positif terhadap profitabilitas. Berdasarkan paparan diatas, maka hipotesis 5 yang diajukan dalam penelitian ini adalah:

$\mathrm{H}_{5 \mathrm{a}}$ :Volume pembiayaan berpengaruh positif terhadap tingkat rentabilitas pada bank umum syariah

$\mathrm{H}_{5 \mathrm{~b}}$ :Volume pembiayaan berpengaruh positif terhadap tingkat rentabilitas pada BPRS

Perbedaan Pengaruh Antar Variabel (NPF, KAP, ART, DPK, dan FDR) Terhadap Tingkat Rentabilitas antara Bank Umum Syariah dan BPR Syariah

Observasi pada penelitian ini dibedakan menjadi dua kelompok, yaitu bank umum syariah (a) dan BPR syariah (b). Penelitian ini menguji apakah nilai pengaruh variabel-variabel dari kedua kelompok (bank umum syariah dan BPR syariah) tersebut bernilai berbeda meskipun merupakan subyek proses ekonomi yang sama dan kategori yang sama yaitu syariah. Oleh karena itu, hipotesis 6 yang diajukan adalah sebagai berikut:

$\mathrm{H}_{0}$ : Tidak terdapat perbedaan pengaruh antar variabel (NPF, KAP, ART, DPK, dan FDR) terhadap 
rentabilitas bank umum syariah dan BPRS

$\mathrm{H}_{6}$ : Terdapat perbedaan pengaruh antar variabel (NPF, KAP, ART, DPK, dan FDR) terhadap rentabilitas bank umum syariah dan BPRS

\section{METODE PENELITIAN \\ Populasi, Penentuan Sampel, Jenis, dan Sumber Data}

Populasi dalam penelitian ini adalah Bank Umum Syariah dan BPRS yang ada di Indonesia. Dalam menentukan sampel untuk memperoleh data yang dibutuhkan, penulis menggunakan teknik purposive sampling (sampling pertimbangan) untuk Bank Umum Syariah, sedangkan untuk BPR Syariah menggunakan cluster sampling. Dalam penelitian ini, yang akan dijadikan sampel adalah 5 bank umum syariah dan BPR Syariah sebanyak 25 bank dari 14 provinsi yang ada di Indonesia. Data diperoleh dari Laporan Keuangan Bank Umum Syariah dan BPRS periode 2011-2013 berupa laporan keuangan triwulanan, data-data yang diperoleh dari situs Bank Indonesia, Neraca BPRS, dan data-data atau informasi keuangan Bank Umum Syariah dan BPRS yang menjadi sampel dalam penelitian, serta sumber lainnya yang berasal dari internet yang mendukung penelitian ini.

\section{Operasionalisasi Variabel Variabel Independen}

a. Risiko pembiayaan $\left(\mathrm{X}_{1}\right)$ yang dipresentasikan oleh NPF (Non Performing Financing) dengan rumus berikut:

$$
N P F=\frac{\text { Pembiayaan Bermasala } h}{\text { Total Pembiayaan }}
$$

(Pramuka 2010)

b. Kualitas aktiva produktif (KAP) dihitung dengan cara mengurangkan satu dengan Aktiva Produktif Yang Diklasifikasikan Non-Performing
(APYD) terhadap total Aktiva Produktif. Kualitas Aktiva Produktif $\left(\mathrm{X}_{2}\right)$ yang diproksikan dengan: $K A P=\frac{\text { Aktiva Produktif }}{\text { Total Aktiva Produktif }} \times 100$

c. Pada perbankan syraiah, total pendapatan dianalogikan dengan total penyaluran pembiayaan dan jumlah piutang dinalogikan dengan jumlah piutang murabahah. Perputaran piutang nasabah $\left(\mathrm{X}_{3}\right)$ diproksikan dengan:

$A R T=\frac{\text { Pembiayaan yang disalurkan }}{\text { Rata-rata Piutang }}$

d. DPK (Dana Pihak Ketiga) dalam penelitian ini sebagai variabel $\mathrm{X}_{4}$ diproksikan dengan jumlah total DPK dalam bentuk rupiah dengan menggunakan rumus hitung LnDPK.

e. Volume pembiayaan sebagai variabel $\mathrm{X}_{5}$ yang diproksikan dengan Financing to Deposit Ratio (FDR) dengan rumus berikut:

$$
\text { FDR }=\frac{\text { Total Pembiayaan }}{\text { Total DPK }}
$$

f. Dalam penelitian ini, size perusahaan sebagai variabel kontrol dengan menggunakan total aset. Size / ukuran perusahaan diukur dengan log natural dari total aset bank, dalam hal ini merujuk pada penelitian Stiawan (2009):

Size perusahaan $=\log n$ Total Aset

\section{Variabel Dependen}

Nilai NOM menurut Surat Edaran Bank Indonesia No. 9 Tahun 2007 mengenai Sistem Penilaian Tingkat Kesehatan Bank Umum Berdasarkan Prinsip Syariah, dalam penelitian Setiawan (2009) diperoleh dengan rumus sebagai berikut:

$\mathrm{NOM}=\frac{(P O-D B H)-B O}{\text { Rata }- \text { rata } A P}$

\section{Metode Analisis Data}

Penelitian ini merupakan penelitian kuantitatif yang 
menggunakan metode analisis data regresi berganda (multiple regression), dimana analisis regresi ini digunakan dalam pengujian hipotesis. Adapun untuk uji kesamaan koefisien antar dua sektor digunakan Chow Test. Sebelumnya dilakukan uji asumsi klasik yang meliputi uji normalitas, multikoliniearitas, heteroskedastisitas, dan autokorelasi. Analisis regresi berganda pada penelitian ini digunakan untuk menguji hipotesis 1a, 1b, 2a, 2b, 3a, 3b, 4a, 4b, 5a, dan 5b. Model yang digunakan dalam penelitian ini adalah:

$\mathrm{NOM}=\alpha+\beta 1 \mathrm{NPF}+\beta 2 \mathrm{KAP}+\beta 3 \mathrm{ART}+\beta 4$ $\mathrm{DPK}+\beta 5 \mathrm{FDR}+\beta 6$ Size $+\varepsilon$

Dimana:

$$
\begin{array}{ll}
\text { NOM } & =\text { Net Operating Margin } \\
\alpha & =\text { Konstanta } \\
\beta 1, \beta 6 & =\text { Koefisien Regresi } \\
\text { NPF } & =\text { Non Performing Financing } \\
\text { KAP } & =\text { Kualitas Aktiva Produktif } \\
\text { ARTO } & =\text { Account Receivable Turnover } \\
\text { DPK } & =\text { Dana Pihak Ketiga } \\
\text { FDR } & =\text { Financing to Deposit Ratio } \\
\text { Size } & =\text { Ukuran perusahaan } \\
& \text { Selain itu, pada penelitian ini }
\end{array}
$$
menggunakan uji t. Oleh karena itu, uji t ini digunakan untuk menguji hipotesis $\mathrm{H}_{1}$ sampai dengan $\mathrm{H}_{5}$. Taraf signifikansi ditetapkan sebesar 5\%, hal ini berarti kemungkinan kebenaran hasil penarikan kesimpulan mempunyai probabilitas 95\% atau toleransi kesalahan adalah $5 \%$, dengan kriteria pengujian jika nilai signifikansi $<\alpha(0,05)$ maka $\mathrm{H}_{0}$ ditolak dan jika nilai signifikansi $>\alpha(0,05)$ maka $\mathrm{H}_{0}$ diterima.

Analisis dengan menggunakan Uji Chow digunakan untuk menguji hipotesis $6\left(\mathrm{H}_{6}\right)$. Rumus dari uji chow test ini adalah sebagai berikut:

$$
\begin{gathered}
\mathrm{F}= \\
\frac{(R S S r-R S S u r / k}{R S S u r /(n 1+n 2-2 k)}
\end{gathered}
$$

Keterangan:

RSSur : RSS sektor 1(Bank Umum Syariah)+RSS sektor 2 (BPRS)

$\mathrm{RSSr}$ : RSS sektor gabungan

RSS : Residual Sum of Square

$\mathrm{n} \quad$ : jumlah observasi

k : jumlah parameter SSRRu

$\mathrm{r} \quad$ : jumlah parameter $\mathrm{SSRu}$

df $\quad:(n 1+n 2-2 k)$

\section{HASIL PENELITIAN DAN PEMBAHASAN}

\section{Analisis Data}

Hasil uji regresi pada bank umum syariah dapat dilihat pada Tabel 1 berikut ini.

Tabel 1

Hasil Perhitungan Regresi Bank Umum Syariah dan BPR Syariah

$\begin{gathered}\text { Bank Umum } \\ \text { Syariah }\end{gathered}$
BPR Syariah

\begin{tabular}{ccccc}
\hline Variabel & $\beta$ & Sig. & B & Sig. \\
\hline Constanta & 63,782 & 0,077 & -16.307 & 0.954 \\
& & & & \\
NPF & $-0,197$ & 0,651 & -0.374 & 0.797 \\
KAP & 1,781 & 0,002 & 15.444 & 0.928 \\
ART & $-0,191$ & 0,027 & -0.629 & 0.991 \\
DPK & 4,500 & 0,005 & 44.772 & 0.766 \\
FDR & 0,057 & 0,031 & -0.215 & 0.163 \\
TA & $-11,210$ & 0,005 & -38.984 & 0.807 \\
\hline
\end{tabular}

Sumber: Output SPSS, diolah kembali 
$\mathrm{NOM}=63,782-0,197 \mathrm{NPF}+1,781$ KAP - 0,191 ART + 4,500 DPK + 0,057 FDR - 11,210 TA + $e$

Berdasarkan pada tabel hasil uji regresi dapat diketahui bahwa ada empat variabel yang berpengaruh secara signifikan terhadap variabel dependennya karena memiliki tingkat signifikansi dibawah 0,05 (sig. < 0,05) yaitu pada variabel kualitas aktiva produktif (KAP) dengan tingkat signifikansi 0,002 , variabel perputaran piutang (ART) dengan tingkat signifikansi 0,027 , variabel dana pihak ketiga dengan tingkat signifikansi 0,005 dan variabel volume pembiayaan (FDR) dengan tingkat signifikansi 0,031 . Sehingga dapat disimpulkan bahwa hipotesis yang menyatakan variabel kualitas aktiva produktif (KAP), variabel perputaran piutang (ART), variabel dana pihak ketiga (DPK), dan variabel volume pembiayaan (FDR) berpengaruh terhadap rentabilitas (NOM) dapat diterima. Sedangkan untuk satu variabel lainnya tidak signifikan terhadap variabel dependennya karena memiliki tingkat signifikansi di atas 0,05 (sig. > 0,05). Variabel tersebut adalah variabel risiko pembiayaan (NPF) dengan tingkat signifikansi 0,651. Sehingga dapat disimpulkan hipotesis yang menyatakan bahwa variabel risiko pembiayaan (NPF) berpengaruh terhadap rentabilitas (NOM) tidak dapat diterima.

Hasil uji regresi pada BPR Syariah juga dapat dilihat pada Tabel $4.1 \mathrm{di}$ atas. Dari hasil perhitungan dengan progam SPSS 16.00 for windows diperoleh hasil persamaan sebagai berikut:

$\begin{aligned} \mathrm{NOM}= & -16.307-0.374 \mathrm{NPF}+15.444 \\ & \text { KAP }-0.629 \mathrm{ART}+44.772 \\ & \text { DPK }-0.215 \mathrm{FDR}-38.984 \\ & \mathrm{TA}+e\end{aligned}$

Berdasarkan pada tabel hasil uji regresi dapat diketahui bahwa semua variabel independen tidak berpengaruh secara signifikan terhadap variabel dependennya karena memiliki tingkat signifikansi di atas 0,05 (sig. > 0,05). Kelima variabel tersebut adalah variabel risiko pembiayaan (NPF) dengan tingkat signifikansi 0,797 , variabel kualitas aktiva produktif (KAP) dengan tingkat signifikansi 0,928 , variabel perputaran piutang (ART) dengan tingkat signifikansi 0,991, variabel dana pihak ketiga (DPK) dengan tingkat signifikansi 0,766 , dan variabel volume pembiayaan (FDR) dengan tingkat signifikansi 0,163.

Sehingga dapat disimpulkan hipotesis yang menyatakan bahwa variabel risiko pembiayaan (NPF), variabel kualitas aktiva produktif (KAP), variabel perputaran piutang (ART), variabel dana pihak ketiga (DPK), dan variabel volume pembiayaan (FDR) berpengaruh terhadap rentabilitas (NOM) tidak dapat diterima.

\section{Hasil Uji Hipotesis 1 (Risiko pembiayaan berpengaruh negatif terhadap tingkat rentabilitas pada bank umum syariah dan BPRS)}

Hasil uji regresi menunjukkan bahwa variabel risiko pembiayaan (NPF) berpengaruh negatif tidak signifikan terhadap tingkat rentabilitas (NOM) pada bank umum syariah. Hal ini searah dengan hasil uji regresi pada BPRS yang menunjukkan bahwa variabel risiko pembiayaan (NPF) berpengaruh negatif tidak signifikan terhadap tingkat rentabilitas (NOM). Hasil penelitian ini searah dengan hasil penelitian yang dilakukan oleh Nusantara (2009) dimana hasil penelitiannya menunjukkan bahwa NPL tidak mempengaruhi besarnya ROA dan Sabir, 
dkk (2012) yang menunjukkan bahwa NPF tidak berpengaruh signifikan terhadap kinerja keuangan Bank Umum Syariah di Indonesia yang diproksikan dengan ROA.

Secara garis besar, hasil penelitian ini baik pada bank umum syariah maupun BPRS menunjukkan bahwa tingkat risiko pembiayaan (NPF) tidak signifikan secara langsung mempengaruhi rentabilitas dikarenakan adanya pembagian risiko yang dibagi antara pihak bank dengan nasabah sebagai peminjam yang mengakibatkan penurunan penerimaan pendapatan bagi pihak bank dari bagi hasil tidak begitu terpengaruh dengan risiko pembiayaan.

\section{Hasil Uji Hipotesis 2 (Kualitas aktiva produktif berpengaruh positif terhadap tingkat rentabilitas pada bank umum syariah dan BPRS)}

Hasil uji regresi menunjukkan bahwa variabel kualitas aktiva produktif (KAP) berpengaruh positif signifikan terhadap tingkat rentabilitas (NOM) pada bank umum syariah. Hasil penelitian ini searah dengan yang dilakukan oleh Luthfihani (2009) yang menunjukkan bahwa kualitas aktiva produktif memberikan pengaruh positif signifikan terhadap profitabilitas. Arah positif dan signifikan dalam hal ini menunjukkan bahwa adanya pengelolaan terhadap aktiva produktif yang efektif sehingga pembiayaan macet yang terdapat pada komponen kualitas aktiva produktif dapat ditekan. Hal tersebut berdampak pada pihak bank yang membentuk cadangan PPAP menjadi lebih rendah sehingga berpengaruh terhadap rentabilitas.

Pada BPRS menunjukkan hasil uji yang berbeda. Hasil uji regresi pada BPRS menunjukkan bahwa variabel kualitas aktiva produktif (KAP) berpengaruh positif tidak signifikan terhadap tingkat rentabilitas (NOM).
Hasil penelitian ini searah dengan hasil penelitian yang dilakukan oleh Chatarine dan Putu (2012) serta Rohimat (2012) yang menunjukkan bahwa kualitas aktiva produktif berpengaruh tetapi tidak signifikan terhadap rentabilitas bank. Kualitas aktiva produktif yang tidak berpengaruh signifikan terhadap rentabilitas (NOM) bisa jadi dikarenakan oleh keadaan ekonomi nasional. Pengaruh dari keadaan ekonomi nasional yang terjadi akhir-akhir ini dan dapat menyebabkan pembiayaan macet, sehingga bank tidak lagi terlalu mengandalkan pendapatan dari penyaluran pembiayaan.

\section{Hasil Uji Hipotesis 3 (Perputaran piutang berpengaruh positif terhadap tingkat rentabilitas pada bank umum syariah dan BPRS)}

Hasil uji regresi menunjukkan bahwa variabel perputaran piutang (ART) berpengaruh negatif signifikan terhadap tingkat rentabilitas (NOM) pada bank umum syariah. Hasil penelitian ini searah dengan penelitiannya Agustini, dkk (2014) yang menunjukkan adanya pengaruh negatif signifikan perputaran piutang terhadap rentabilitas dan hasil penelitian ini juga konsisten dengan pernyataan Munawir (2007) yang mengungkapkan bahwa perputaran piutang mempengaruhi rentabilitas ekonomi karena semakin tinggi tingkat perputaran piutang maka semakin rendah rentabilitas ekonomis. Seharusnya, semakin cepat perputaran piutang berarti semakin kecil atau pendek jangka waktu pengembalian pinjaman pembiayaan. Akan tetapi pada hasil penelitian ini menunjukkan hasil yang berbeda. Hal ini dikarenakan pada beberapa tahun terakhir kebanyakan bank umum syariah lebih fokus pada penawaran pembiayaan jangka panjang, sehingga perolehan margin pun lebih 
besar jika dibandingkan dengan pembiayaan jangka pendek.

Pada BPRS, hasil penelitian menunjukkan bahwa perputaran piutang (ART) berpengaruh negatif tidak signifikan. Hal tersebut terjadi pada BPRS dalam melakukan penyaluran pembiayaan, terutama pada sektor pembiayaan jangka pendek dan modal kerja. Meskipun margin yang diterima tidak begitu besar, akan tetapi dana yang diperoleh dapat langsung diinvestasikan kembali dalam bentuk pembiayaan. Temuan ini konsisten dengan hasil penelitian Suarnami dkk (2014) yang menyatakan bahwa perputaran piutang secara langsung tidak berpengaruh signifikan terhadap profitabilitas pada perusahaan pembiayaan.

\section{Hasil Uji Hipotesis 4 (Dana pihak ketiga berpengaruh positif terhadap tingkat rentabilitas pada bank umum syariah dan BPRS)}

Hasil uji regresi menunjukkan bahwa variabel dana pihak ketiga (DPK) berpengaruh positif signifikan terhadap tingkat rentabilitas (NOM) pada bank umum syariah. Hasil penelitian pada bank umum syariah searah dengan penelitian yang dilakukan oleh Ayu (2007) menyatakan bahwa tabungan dan deposito mempunyai pengaruh yang signifikan terhadap tingkat rentabilitas syariah dan penelitian yang dilakukan oleh Sudiyatno dan Suroso (2010) yang menunjukkan bahwa dana pihak ketiga (DPK) berpengaruh positif dan signifikan terhadap kinerja bank. Semakin tinggi rasio ini, maka semakin baik tingkat kepercayaan masyarakat terhadap bank yang bersangkutan, baik dalam menyimpan uangnya di bank sehingga mampu meningkatkan laba operasional dari hasil menyalurkan DPK dalam bentuk pembiayaan kepada nasabah. Dengan demikian, tingkat rentabilitas pun menjadi meningkat.

Akan tetapi pada BPRS juga menunjukkan hasil uji yang berbeda. Hasil uji regresi menunjukkan bahwa variabel dana pihak ketiga (DPK) berpengaruh positif tidak signifikan terhadap tingkat rentabilitas (NOM). Hasil penelitian pada BPR syariah ini searah dengan Yuliani (2007) yang menunjukkan bahwa dana pihak ketiga tidak berpengaruh secara signifikan terhadap profitabilitas. Adanya pengaruh yang tidak signifikan dalam hal ini adalah dimungkinkannya terjadi dua hal. Pertama, terdapat peningkatan dana pihak ketiga (DPK) tetapi peningkatan tersebut relatif kecil, mengingat nisbah bagi hasil pada bank syariah tidak sebesar tingkat bunga simpanan pada bank konvensional, serta adanya persaingan antar bank. Kedua, banyaknya dana yang menganggur akibat dari kenaikan jumlah dana pihak ketiga, akan tetapi tidak diikuti dengan efektifitas penyalurannya melalui pembiayaan.

\section{Hasil Uji Hipotesis 5 (Volume pembiayaan berpengaruh positif terhadap tingkat rentabilitas pada bank umum syariah dan BPRS)}

Hasil uji regresi menunjukkan bahwa variabel volume pembiayaan berpengaruh positif signifikan terhadap tingkat rentabilitas (NOM) pada bank umum syariah. Hasil penelitian ini seiring dengan hasil penelitian Pramuka (2010), Stiawan (2009), dan Sabir, dkk (2012) yang menunjukkan bahwa variabel besarnya pembiayaan (FDR) mempunyai pengaruh positif dan signifikan terhadap profitabilitas bank umum syariah. Adapun nilai positif yang ditunjukkan oleh FDR menandakan bahwa semakin tinggi FDR mengindikasikan bahwa semakin bagus pula kondisi likuiditas bank 
dikarenakan adanya efektifitas yang baik dalam pengelolaan dan penyalurannya. Hal itu dapat dilihat dari banyaknya bank umum syariah yang mempunyai nilai FDR $>80 \%$ dan nilai FDR $<110 \%$. Peningkatan FDR berarti penyaluran dana ke pinjaman semakin besar, sehingga keuntungan yang diperoleh bank tersebut akan meningkat.

Akan tetapi, pada BPRS menunjukkan hasil uji yang berbeda. Hasil uji regresi menunjukkan bahwa variabel FDR berpengaruh negatif tidak signifikan terhadap tingkat rentabilitas (NOM). hasil pada BPRS sejalan dengan penelitian Yuliani (2007) dan Suryani (2011) yang menunjukkan bahwa FDR tidak berpengaruh terhadap

profitabilitas bank. Hal tersebut merupakan dampak dari adanya peningkatan volume pembiayaan yang kurang memperhatikan prinsip kehatihatian sehingga Non Performing Financing (NPF) tidak dapat dijaga dalam kisaran yang stabil.

Pengaruh Risiko Pembiayaan (NPF),
Kualitas Aktiva Produktif (KAP),
Perputaran Piutang (ART), Dana
Pihak Ketiga (DPK), Volume
Pembiayaan (FDR) Terhadap
Rentabilitas (NOM) dengan Total
Aset Sebagai Variabel Kontrol
Hasil uji regresi pada bank
umum syariah sebelum adanya total aset
sebagai variabel kontrol adalah sebagai
berikut:

Tabel 2

Uji Regresi Bank Umum Syariah Sebelum dan Setelah Ada Variabel Kontrol

\begin{tabular}{ccccc}
\hline & \multicolumn{3}{c}{ Sebelum Ada Total Aset } & \multicolumn{2}{c}{ Setelah Ada Total Aset } \\
\hline Variabel & $\mathrm{t}$ & Sig. & $\mathrm{T}$ & Sig. \\
\hline (Constant) & 2,957 & 0,025 & 63,782 & 0,077 \\
NPF & 0,224 & 0,830 & $-0,197$ & 0,651 \\
KAP & $-1,625$ & 0,155 & 1,781 & 0,002 \\
ART & $-1,917$ & 0,104 & $-0,191$ & 0,027 \\
DPK & $-1,571$ & 0,167 & 4,500 & 0,005 \\
FDR & 0,182 & 0,862 & 0,057 & 0,031 \\
TA & & & $-11,210$ & 0,005 \\
\hline
\end{tabular}

Sumber: Output SPSS, diolah kembali

Sebelum adanya total aset, kelima variabel yang diteliti (NPF, KAP, ART, DPK, dan FDR) tidak berpengaruh terhadap rentabilitas (NOM). Akan tetapi, setelah adanya total aset sebagai variabel kontrol, ternyata terdapat empat variabel yang berpengaruh. Keempat variabel tersebut adalah kualitas aktiva produktif (KAP), perputaran piutang (ART), dana pihak ketiga (DPK) dan volume pembiayaan (FDR). Dengan adanya total aset ternyata ada empat variabel yang

pengaruhnya signifikan. Adanya asumsi bahwa jika semakin besar suatu perusahaan, maka kualitas asetnya pun semakin bagus, dikarenakan perusahaan tersebut mampu berinvestasi. Karena dalam hal ini yang dijadikan perusahaan adalah bank, dengan adanya perkembangan bank yang semakin meningkat, hal itu mampu meningkatkan keprcayaan pada nasabah yang akhirnya berujung pada meningkatnya dana yang terhimpun dari masyarakat. Dengan demikian, pihak 
bank otomatis memiliki aset yang besar berupa dana untuk disalurkan melalui pembiayaan dan akhirnya aset tersebut dapat meningkatkan rentabilitas.

Tabel 3

Uji Regresi Bank Pembiayaan Rakyat Syariah (BPRS) Sebelum dan Setelah Ada Variabel Kontrol

\begin{tabular}{ccccc}
\hline & \multicolumn{2}{c}{$\begin{array}{c}\text { Sebelum Ada Total } \\
\text { Aset }\end{array}$} & \multicolumn{2}{c}{$\begin{array}{c}\text { Setelah Ada Total } \\
\text { Aset }\end{array}$} \\
\hline Variabel & T & Sig. & T & Sig. \\
\hline (Constant) & -0.311 & 0.767 & $-0,061$ & 0,954 \\
NPF & -0.331 & 0.752 & $-0,272$ & 0,797 \\
KAP & 0.245 & 0.815 & 0,095 & 0,928 \\
ART & -0.225 & 0.83 & $-0,012$ & 0,991 \\
DPK & 0.768 & 0.472 & 0,315 & 0,766 \\
FDR & -1.943 & 0.1 & $-1,635$ & 0,163 \\
TA & & & $-0,258$ & 0,807 \\
\hline
\end{tabular}

Sumber: Output SPSS, diolah kembali

Berdasarkan tabel di atas, risiko pembiayaan (NPF), kualitas aktiva produktif (KAP), perputaran piutang (ART), dana pihak ketiga (DPK), dan volume pembiayaan (FDR) pada BPR Syariah tidak mempengaruhi rentabilitas, baik sebelum maupun setelah adanya total aset sebagai variabel kontrol. Adanya gap yang cukup signifikan pada total aset antar BPR Syariah yang tidak merata, mengakibatkan kelima variabel tersebut tidak berpengaruh. Besarnya total aset yang dimiliki oleh BPRS tidak serta merta diimbangi dengan minat masyarakat untuk menjadi nasabah di BPRS. Hal itu disebabkan karena selama ini jangkauannya terfokus pada masyarakat menengah kebawah yang tidak terjangkau oleh bank umum. Akan tetapi sama halnya pada bank umum syariah, total aset mempunyai pengaruh negatif, bahkan pada BPR syariah cenderung tidak signifikan.

\section{Hasil Uji Chow}

Berdasarkan tabel $\mathrm{F}$ dengan $\mathrm{df}=$ 6 dan 12 dengan tingkat signifikansi 0.05 didapat nilai $\mathrm{F}$ tabel 3,00 dan $\mathrm{F}$ hitung 19,46. Oleh karena $\mathrm{F}$ hitung $>\mathrm{F}$ tabel, dapat disimpulkan bahwa adanya total aset sebagai variabel kontrol mempengaruhi stabilitas model regresi pada bank umum syraiah dan BPRS. Dengan kata lain hubungan antara variabel risiko pembiayaan, kualitas aktiva produktif, perputaran piutang, dana pihak ketiga, dan volume pembiayaan baik di bank umum syariah maupun di BPR syariah mempunyai pengaruh yang berbeda terhadap rentabilitas.

\section{Simpulan Dan Implikasi}

\section{Simpulan}

1. Risiko pembiayaan (NPF) tidak berpengaruh terhadap tingkat rentabilitas (NOM), sedangkan kualitas aktiva produktif (KAP), perputaran piutang (ART), dana pihak ketiga (DPK) dan volume pembiayaan (FDR) berpengaruh terhadap tingkat rentabilitas (NOM) pada bank umum syariah.

2. Risiko pembiayaan (NPF), kualitas aktiva produktif (KAP), perputaran piutang (ART), dana pihak ketiga (DPK), dan volume pembiayaan (FDR) tidak berpengaruh terhadap 
tingkat rentabilitas (NOM) pada BPRS.

3. Berdasarkan hasil uji chow bahwa model regresi pada bank umum syraiah dan BPRS adalah sama, dengan demikian hubungan antara setiap variabel untuk masing-masing model regresi mempunyai pengaruh yang sama dan dalam katageri sejenis yaitu syariah.

\section{Implikasi}

Hasil Penelitian ini menunjukkan bahwa rasio-rasio keuangan bank untuk kategori bank umum syariah (terutama KAP, ART, DPK, dan FDR) mampu memprediksi NOM pada bank umum syariah di Indonesia periode 2011-2013. Sedangkan untuk kategori BPR syariah tidak ada yang mampu memprediksi NOM. Sisi positif dari hasil penelitian ini adalah mempertegas hasil penelitian sebelumnya (Pramuka, 2010; Luthfihani, 2009; Theresia, 2009; dan Rohimat, 2012) dimana hasil penelitian ini menegaskan bahwa variabel KAP, ART, DPK, dan FDR berpengaruh terhadap NOM bank umum syariah. Dengan demikian bahwa pihak manajemen bank umum syariah harus lebih memperhatikan kualitas aset, perputaran piutang,dana pihak ketiga, dan penyaluran pembiayaan, karena variabel-variabel tersebut yang paling dominan dan konsisten dalam mempengaruhi NOM.

\section{Daftar Pustaka}

Al Arif, M. Nur Rianto. 2012. Lembaga Keuangan Syariah, Suatu Kajian Teoretis Praktis. Bandung: Pustaka Setia.

Antonio, M. Syafi'i. 2001. Bank Syariah Dari Teori Ke Praktik. Jakarta: Gema Insani.

Arifin, Zainul. 2006, Dasar-dasar Manajemen Bank Syariah. Jakarta: AlvaBet.

Ayu, Dewi Gusti. 2007. Pengaruh Tabungan Dan Deposito
Terhadap Rentabilitas Pada Bank Umum. Program Studi Manajemen Perbankan, Universitas Gunadarma.

Arsyianti, Laily Dwi. 2012. http://jurnalekis.blogspot.com/2

012/01/manajemen-stakeholderdalam-

syariah.html\#sthash.wXt2Wlo1.

dpuf, diakses tanggal 26

November 2013.

Bank Indonesia, 2007. Surat Edaran Bank Indonesia (SEBI) No. 9 Tahun 2007 mengenai Sistem Penilaian Tingkat Kesehatan Bank Umum Berdasarkan Prinsip Syariah.

Brissimis Anthonasoglou. 2005. Bank spesific industry, and specific makroekonomic determinant of bank profitabilitas. Working paper, bank of Greece. No. 25. June.

Brigham, Eugene F. dan Joel F. Houston. 2010. Dasar-dasar Manajemen Keuangan, Edisi 11. Jakarta: Salemba Empat.

Damastuti, Isnaini Endah. 2010. Analisis Perbandingan Kinerja Keuangan Bank Syariah dengan Menggunakan Income Statement Approach dan Value Added Approach (Studi Kasus Bank Muamalat Indonesia Cabang Semarang). Semarang: Universitas Diponegoro.

Dendawijaya, Lukman. 2005. Manajemen Perbankan. Jakarta: Penerbit Ghalia Indonesia.

Dewi, Citra Sylvia. 2012. Pengaruh Kredit Bermasalah Dan Kualitas Aktiva Produktif Terhadap Profitabilitas Bank Pada Sektor Perbankan Go Publik Yang Terdaftar Di Bursa Efek Indonesia Tahun 20102012. Universitas Komputer Indonesia. 
Gary C. Zimmerman, 1996. Factor Influencing Community Bank Performance in California, FBRSF Economic Review.

Gray, Rob, Reza Kouhy, dan Simon Lavers. 1995. "Corporate Social and Environmental Reporting: A Review of The Litetrature and A Longitudinal Study of UK Disclosure". Accounting, Auditing, and Accountability Journal Vol. 8, No. 2, pp 47-77.

Harmanta dan Mahyus Ekanada. 2005.

Disintermediasi Fungsi

Perbankan di Indonesia Pasca

krisis 1997: Faktor Permintaan atau Penawaran Kredit, Sebuah pendekatan dengan Model Disequilibrium. Buletin Ekonomi Moneter dan Perbankan, Edisi Juni 2005.

http://qamaruddinshadie.blogspot.com/ 2012/04/bank-pembiayaanrakyat-syariah.html, diakses pada tanggal 15 Januari 2014.

Imam Ghozali. 2006. Aplikasi Analisis Multivariate dengan Program SPSS. Cetakan Keempat. Semarang: Badan Penerbit Undip.

Islam, Mohd. Aminul. 2012. An Appraisal Of The Performance Of Two (2) Development Financial Institutions (DFIs) In Malaysia. International Journal Of Economics And Management Sciences Vol. 1, No. 7, 2012, Pp. 64-74.

Jordan, Sarah. 2013. Islamic Banks and Profitability: An Empirical Analysis of Indonesian Banking. A Dissertation presented in part consideration for the degree of MSc in Finance and Investment: Nottingham University.

Kasmir. 2007. Manajemen Perbankan. Jakarta: PT Raja GrafindoPersada.
Khan, Tariqullah and Ahmed, Habib, 2001. Risk Management: An Analysis of Issues in Islamic Financial Industry. Jeddah: IRTI-IDB.

Lestari, Maharani Ika dan Toto Sugiharto. 2007. Kinerja Bank Devisa Dan Bank Non Devisa Dan Faktor-Faktor Yang Mempengaruhinya. Proceeding PESAT (Psikologi, Ekonomi, Sastra, Arsitek \& Sipil). 21-22 Agustus, Vol.2. Fakultas Ekonomi, Universitas Gunadarma.

Luthfihani, Chindy Anggraeni. 2009. Pengaruh Kualitas Aktiva Produktif (KAP) dan Kredit Bermasalah Terhadap Profitabilitas Pada PT. Bank Negara Indonesia (Persero) Tbk - Universitas Komputer Indonesia: Bandung.

Meutia, Inten. 2010. "Shariah Enterprise Theory sebagai Dasar Pengungkapan Tanggung Jawab Sosial untuk Bank Syariah". Disertasi Tidak Dipublikasikan, Doktor Ilmu Akuntansi Program Pascasarjana, Universitas Brawijaya.

Muhammad. 2005. Manajemen Pembiayaan Bank Syariah. Yogyakarta: UPP AMP YKPN.

Muhammad. 2013. Akuntansi Syariah, Teori dan Praktik Untuk Perbankan Syariah. Edisi Pertama, cetakan pertama. Yogyakarta: UPP STIM YKPN.

Munawir, S. 2007. Analisa Laporan Keuangan. Edisi Keempat. Yogyakarta: Liberty.

Muljono, Teguh Pudjo. 1996. Análisis Laporan Keuangan Perbankan.

Cetakan ke

Enam. Jakarta: Penerbit Djambatan. 
Mawardi, Wisnu. 2005. Analisis Faktorfaktor Yang Mempengaruhi Kinerja Keuangan Bank Umum di Indonesia (Studi Kasus Pada Bank Umum Dengan Total Assets Kurang Dari 1 Triliun). Jurnal Bisnis Dan Strategi. Vol.14. No.1.

Nurhayati, Sri dan Wasilah. 2008. Akuntansi Syariah Di Indonesia. Jakarta : Salemba Empat.

Pramuka, Bambang Agus. 2010. Faktorfaktor Yang Berpengaruh Terhadap Tingkat Profitabilitas Bank Umum Syariah. (JAMBSP Vol. 7 No. 168 -Oktober 2010: 67).

Purwana, Edward Gagah. 2009. Analisis Pengaruh Capital Adequacy Ratio (CAR), Loan To Deposit Ratio (LDR), Size, BOPO Terhadap Profitabilitas (Studi Perbandingan Pada Bank Domestik Dan Bank Asing Periode Januari 2003-Desember 2007). Tesis Magister Manajemen Program Studi Magister Manajemen Universitas Diponegoro.

Purwitasari, Fadilla dan Anis Chariri. 2010. Analisis Pelaporan Corporate Social Responsibility Perbankan Syariah Dalam Perspektif Shariah Enterprise Theory: Studi Kasus Pada Laporan Tahunan Bank Syariah Mandiri Dan Bank Muamalat Indonesia. Jurnal Penelitian Universitas Diponegoro: Semarang.

Rindhatmono, Ferdi. 2005. Analisis Faktor-Faktor Yang Mempengaruhi Profitabilitas Bank Pasca Merger Di Indonesia. Tesis Magister Manajemen Universitas Diponegoro: Semarang.
Ridha, Nugraha. 2012. Manajemen Pembiayaan Panduan Untuk Koperasi Syariah SDM Kementerian Koperasi. Artikel diakses pada 12 Desember 2013 dari

http://hasbullah.multiply.multipl ycontent.com.

Riadi, Slamet. 2004. Banking Assets And Liability Management. Edisi 2. Jakarta: Lembaga Penerbit Universitas Indonesia.

Roslina , Michael Hadjaat, dan Maryam Nadir. 2012. Analisis Perputaran Piutang Debitur Golongan A, B, C Dan D Pada Perum Pegadaian Cabang Samarinda. Fakultas Ekonomi Universitas Mulawarman: Samarinda.

Rohimat, Rudi. 2012. Pengaruh Kecukupan Modal Dan Kualitas Aktiva Produktif Terhadap Rentabilitas Bank (Studi Kasus Pada PT. BPR Poladana Tasikmalaya). Program Studi Akuntansi Fakultas Ekonomi Universitas Siliwangi: Tasikmalaya.

Stiawan, Adi. 2009. Analisis Pengaruh Faktor Makroekonomi, Pangsa Pasar Dan Karakteristik Bank Terhadap Profitabilitas Bank Syariah (Studi Pada Bank Syariah Periode 2005-2008). Tesis Magister Manajemen Program Studi Magister Manajemen Universitas Diponegoro: Semarang.

Suyono, Agus. 2005. Analisis Rasiorasio Bank Yang Berpengaruh Terhadap ROA (Studi Empiris: Pada Bank Umum di Indonesia Periode 2001-2003 ). Tesis Magister Manajemen Program Studi Magister Manajemen Universitas Diponegoro: Semarang. 
Setiawan, Azis Budi. 2009. Kesehatan Finansial dan Kinerja Sosial Bank Umum Syariah di Indonesia. Materi Seminar Ilmiah Kerjasama Magister Bisnis Keuangan Islam Univ. Paramadina, Ikatan Ahli Ekonomi Islam (IAEI) Pusat dan Masyarakat Ekonomi Syariah (MES).

Sudiyatno, Bambang dan Jati Suroso. 2010. Analisis Pengaruh Dana Pihak Ketiga, BOPO, CAR dan LDR Terhadap Kinerja Keuangan Pada Sektor Perbankan Yang Go Public Di Bursa Efek Indonesia (Periode 2005-2008). Jurnal Dinamika Keuangan dan Perbankan, Mei 2010, hal.125-137.

Sinungan, Muchdarsyah. 2000. Manajemen Dana Bank. Edisi kedua. Jakarta: PT. Bumi Aksara.

Sugiyono. 2008. Metode Penelitian Bisnis. Bandung: Alfabeta.

Susanto, Burhanudin. 2008. Hukum Perbankan Syariah di Indonesia. Yogyakarta: UII Press.

Suryani. 2011. Analisis Pengaruh Financing To Deposit Ratio (FDR) Terhadap Profitabilitas Perbankan Syariah Di Indonesia. STAIN Malikussaleh Lhokseumawe. Walisongo, Volume 19, Nomor 1, Mei 2011.

Susilawati, Susi dan Asep Ghofir Ali. 2010. Pengaruh Pembiayaan Mudharabah Terhadap Non Performing Financing (NPF) Pada Bank Pembiayaan Rakyat Syariah (BPRS). Bandung: STIE EKUITAS.

Siamat, Dahlan. 2005. Manajemen Lembaga Keuangan. Edisi Keempat. Jakarta: Lembaga Penerbit FEUI.
Sabir, Muh, Muhammad Ali, dan Abd. Hamid Habbe. 2012. Analisis Pengaruh Rasio Kesehatan Bank Terhadap Kinerja Keuangan Bank Umum Syariah dan Bank Konvensional di Indonesia. Jurnal Analisis, Juni 2012, Vol.1 No. $1: 79-86$.

Slamet, M. 2001. "Enterprise Theory dalam Konstruksi Akuntansi Syari'ah (Studi Teoritis pada Konsep Akuntansi Syari'ah). Fakultas Ekonomi, Universitas Brawijaya: Malang.

Statistik Perbankan Syariah Tahun 2012, Bank Indonesia.

Statistik Perbankan Indonesia Tahun 2012, Bank Indonesia.

Surat Edaran Bank Indonesia (SEBI) No. 9 Tahun 2007 mengenai Sistem Penilaian Tingkat Kesehatan Bank Umum Berdasarkan Prinsip Syariah.

Suliyanto. 2011. Ekonometrika Terapan: Teori dan Aplikasi dengan SPSS. Yogyakarta: Penerbit CV. Andi Offset.

Sumitro, Warkum. (2004), Asas-Asas Perbankan Islam dan LembagaLembaga Terkait. Jakarta: Raja Grafindo Persada.

Taswan. 2009. Manajemen Perbankan Konsep Teknik \& Aplikasi Bangking Risk Assessment. Yogyakarta: UUP STIM YKPN. Theresia O.S, Esther. 2009. Pengaruh Perputaran Piutang Usaha dan Perputaran Persediaan Terhadap Tingkat Rentabilitas Perusahaan Otomotif dan Komponennya yang Terdaftar di BEI. Fakultas Ekonomi Universitas Sumatera Utara: Medan.

Triyuwono, Iwan. 2003. "Sinergi Oposisi Biner: Formulasi Tujuan Dasar Laporan Keuangan Akuntansi Syari'ah". IQTISAD 
Journal of Islamic

Economics, Vol. 4, No. 1, h. 79-

90.

Triyuwono, I. 2006. Perspektif,

Metodologi. Dan Teori

Akuntansi Syariah. Edisi Satu.

Jakarta: PT RajaGrafindo

Persada.

Undang - Undang No. 21 tahun 2008

Tentang Perbankan Syariah.

Undang-Undang No.10 Tahun 1998

Tentang Perbankan.

Yuliani. 2007. Hubungan Efisiensi

Operasional dengan Kinerja

Profitabilitas pada Sektor

Perbankan yang Go Public di

Bursa Efek Jakarta. Jurnal

Manajemen dan Bisnis

Sriwijaya, Vol. 5, No. 10,

Desember, 2007.

Yuniarti, Eti. 2008. "Analisis Pengungkapan Informasi tanggung Jawab Sosial pada Sektor Perbankan di Indonesia." Tesis Tidak Dipublikasikan, Program Studi Magister Sains Akuntansi, Universitas Diponegoro. 